\title{
PENGARUH KONTAMINASI LOGAM BERAT DI SEDIMEN PADA KOMUNITAS MAKROZOOBENTOS DI BEBERAPA SITU DAN WADUK DI JAWA BARAT (Effect of Heavy Metals Contamination in Sediments on The Macrozoobenthos Community in Some Small Lakes and Reservoirs)
}

\author{
Jojok Sudarso*, Tri Suryono dan Gunawan Pratama Yoga \\ Pusat Penelitian Limnologi, Lembaga Ilmu Pengetahuan Indonesia, \\ Jl. Jakarta-Bogor Km 46, Cibinong, Kabupaten Bogor 16911. \\ *Penulis korespondensi. Tel: 085780521768. Email: denmaskoyoy@hotmail.com.
}

Diterima: 17 Juni 2015
Disetujui: 25 September 2015

\begin{abstract}
Abstrak
Keberadaan logam berat di ekosistem akuatik telah sering dilaporkan menimbulkan masalah ke biota perairan. Salah satu biota perairan yang memiliki resiko untuk terpapar logam berat dari sedimen adalah organisme makrozoobentos. Penelitian ini bertujuan untuk mendeskripsikan pengaruh kontaminasi logam berat di sedimen pada struktur komunitas makrozoobentos yang berada di ekosistem lentik (situ dan waduk). Penelitian ini telah dilakukan pada bulan Juni 2009 September 2011 di beberapa situ dan waduk yang berada di Provinsi Jawa Barat dan Jakarta. Sampel makrozoobentos dikumpulkan dengan menggunakan alat Ekman grab. Hasil penelitian menunjukkan bahwa terdapat korelasi antara indeks keanekaragaman makrozoobentos dengan kontaminasi logam arsen yang tinggi. Kontribusi logam $\mathrm{Pb}$ dan $\mathrm{Cd}$ dalam memberikan pengaruh pada indeks keanekaragaman relatif masih kecil. Keberadaan makrozoobentos Coleoptera (Simsonia sp.), lintah (Placobdella sp.), larva chironomid (Ablabesmyia sp.), dan (Tanytarsus sp.) relatif toleran dengan kontaminasi logam arsen di sedimen yang tinggi, $\mathrm{pH}$ dan suhu yang rendah. Penggunaan indeks keanekaragaman pada penelitian ini masih relatif sensitif dalam mencerminkan gangguan akibat kontaminasi logam berat di sedimen.
\end{abstract}

Kata kunci: logam berat, makrozoobentos, sedimen, situ, waduk, polutan.

\begin{abstract}
Presence of heavy metals in aquatic ecosystems have been reported to cause problems in aquatic organisms. One of the aquatic organisms that have risk for exposure by heavy metals from sediments is macrozoobenthos. This paper aims to describe the influence of heavy metal contamination in sediments to the structure of macrozoobenthos communities in lentic ecosystem (small lakes and reservoirs). This study was conducted in June 2009 to September 2011 in some small lakes and reservoirs which are in West Java and Jakarta provinces. Macrozoobenthos samples were collected by using Ekman grab. The results showed that there is a low correlation index with a high diversity of macrozoobenthos contamination by arsenic. The contribution of $\mathrm{Pb}$ and $\mathrm{Cd}$ in giving effect to diversity index is relatively small. The existence of macrozoobenthos Coleoptera (Simsonia sp.), Leeches (Placobdella sp.), Chironomid larvae (Ablabesmyia sp.), and (Tanytarsus sp.) relatively tolerant to high contamination arsenic in sediment, and low $p H$ and temperature. The use of diversity index in this study was relatively sensitive to reflect the disruption caused by heavy metal.
\end{abstract}

Keywords: heavy metals, macrozoobenthos, sediment, small lakes, reservoirs, pollutant.

\section{PENDAHULUAN}

Waduk dan situ merupakan salah satu bentuk ekosistem perairan tawar tergenang yang sumber airnya bersumber dari air tanah maupun permukaan (Anonim 2015). Di daerah Jawa Barat, keberadaan situ maupun waduk relatif banyak dijumpai. Kurang lebih terdapat 596 buah situ dan tiga waduk besar yang berlokasi di sekitar daerah Jawa Barat (Anonim, 2008 a). Keberadaan situ dan waduk memiliki peran penting dari sisi ekonomi misalnya sebagai tempat pariwisata, budidaya ikan, dan pengatur fungsi hidrologi (sumber cadangan air, mengurangi volume air permukaan, dan penahan intrusi air asin) maupun iklim mikro suatu kawasan
(Anjani dkk., 2012). Pemanfaatan fungsi situ di Jabodetabek sebagian besar berguna untuk irigasi sebesar $44 \%$, tandon air/reservoir (31\%), pengendali banjir (10\%), perikanan (8\%), wisata alam (3\%), dan lain-lain (4\%) (Anonim, 2015).

Keberadaan aktivitas antropogenik di sekitar situ maupun waduk berupa pemukiman penduduk maupun industri telah diketahui dapat secara langsung menurunkan kondisi kualitas air maupun kelayakan hidup bagi biota akuatik (Callisto dkk., 2005). Salah satu biota akuatik yang berpotensi terkena dampak dari aktivitas antropogenik adalah organisme bentik makroavertebrata atau makrozoobentos (Moreno dan Callisto, 2006). Organisme tersebut sering digunakan untuk menilai 
status mutu perairan, karena sifatnya yang relatif sesil, sensitivitasnya yang bervariasi dari yang tinggi hingga toleran, relatif mudah diidentifikasi hingga level genus, dan memiliki kemampuan dalam mengakumulasi bahan polutan (Rossaro dkk., 2007; Tall dkk., 2008).

Salah satu bahan toksikan yang dihasilkan dari aktivitas antropogenik ke ekosistem perairan adalah logam berat. Di lingkungan perairan, keberadaan logam berat memiliki kemampuan untuk berikatan dengan bahan partikulat dan terakumulasi di dasar perairan sebagai sedimen (Khaled dkk., 2006; Baldwin dan Howitt, 2007). Sedimen seringkali mengandung konsentrasi logam yang sangat tinggi, sehingga mampu menyebabkan gejala toksisitas bagi biota akuatik maupun kesehatan bagi manusia (Doi dkk., 2007; Farkas dkk., 2007; Prica dkk., 2007; Rippey dkk., 2007). Dampak negatif dari toksisitas logam di sedimen bagi komunitas makrozoobentos yaitu mulai dari terganggunya proses fisiologi, kecacatan morfologi, hingga perubahan pada struktur komunitas yang pada akhirnya berakibat pada menurunnya integritas biotik perairan (Mayer-Pinto dkk., 2010; Di Virolli dkk., 2014).

Beberapa logam berat yang diketahui memiliki daya toksisitas tinggi bagi manusia dan biota akuatik adalah timah hitam (Pb), kadmium (Cd), dan arsen (As) (Appenroth 2010; Pham dkk., 2007). Keberadaan logam berat tersebut seringkali ada dalam limbah industri dan maupun perkotaan yang melalui saluran pembuangan masuk ke dalam ekosistem perairan seperti situ dan waduk. Sebagian besar organisme makrozoobentos mengadakan kontak dengan sedimen dan kolom air, maka potensi untuk terpapar oleh logam berat yang bioavailable semakin besar dan dapat menimbulkan toksisitas maupun kematian bagi hewan tersebut. Oleh sebab itu diperlukan penelitian tentang dampak negatif dari kontaminasi logam berat yang ada di sedimen pada biota akuatik yang sering mengadakan kontak dengan sedimen sebagai habitatnya. Tujuan dari penelitian ini adalah untuk mendeskripsikan pengaruh dari kontaminasi logam berat di sedimen pada struktur komunitas makrozoobentos yang berada di ekosistem lentik (situ dan waduk).

\section{METODE PENELITIAN}

\section{Waktu dan Lokasi}

Penelitian ini telah dilakukan pada bulan Juni 2009 hingga bulan September 2011 di beberapa situ dan waduk yang berlokasi di Jawa Barat dan Jakarta. Tempat lokasi penelitian dapat dilihat dalam Gambar 1. Ada 20 situ dan waduk yang terpilih sebagai titik lokasi penelitian yang didasarkan dari macam gangguan yang ditimbulkan dari aktivitas antropogenik. Tabel 1 merupakan lokasi sampling dan karakteristik tipe gangguan aktivitas antropogenik potensial yang terjadi di sekitar lokasi penelitian.

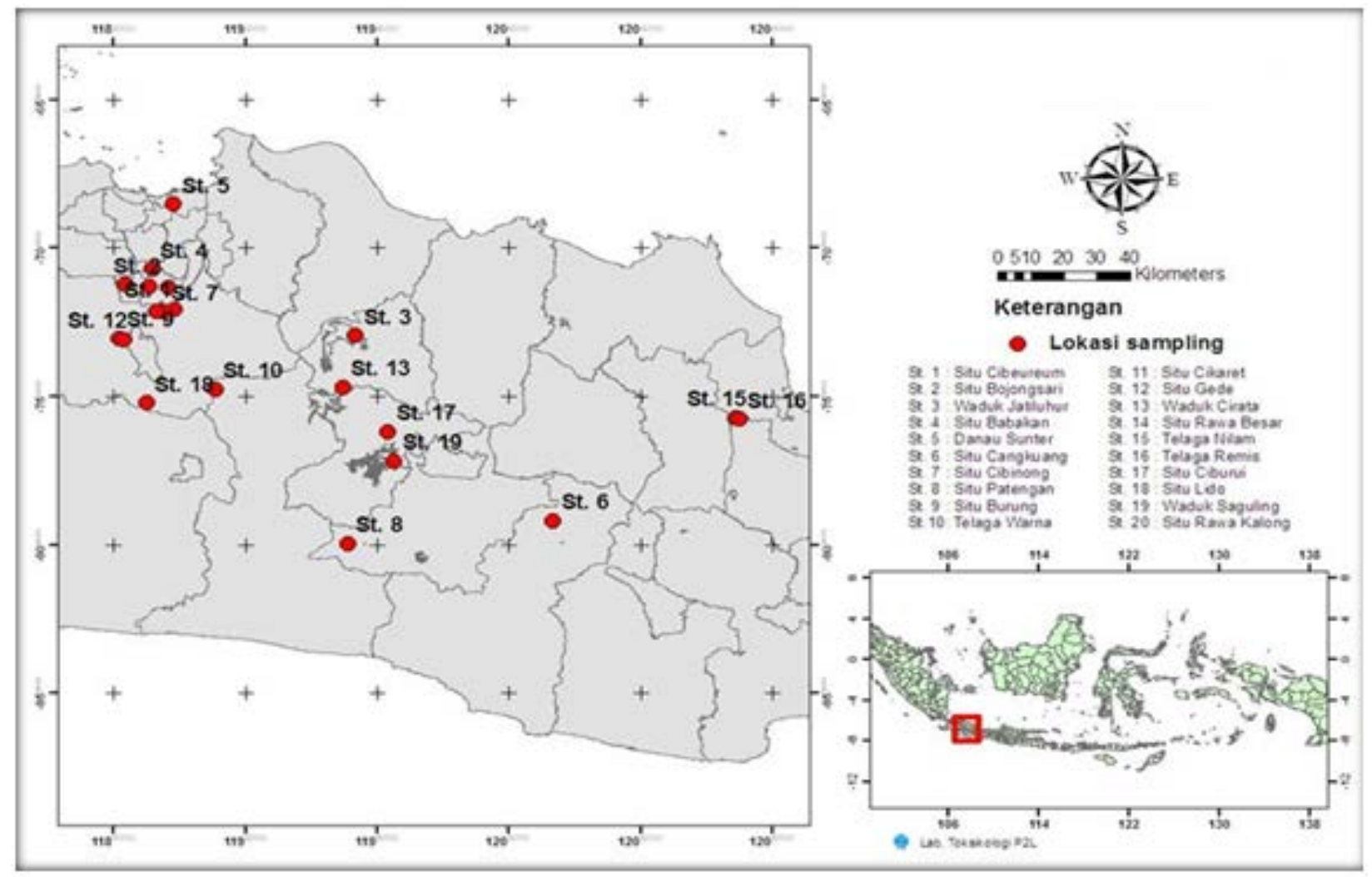

Gambar 1. Peta lokasi penelitian. 
Tabel 1. Nama lokasi situ dan waduk yang digunakan selama penelitian beserta macam tipe gangguannya.

\begin{tabular}{|c|c|c|}
\hline Lokasi & Posisi & Keterangan \\
\hline \multirow[t]{2}{*}{ St. 1. Situ Cibeureum } & $6^{\circ} 27^{\prime} 39,30 ” S$ & - Dekat jalan raya \\
\hline & $106^{\circ} 53^{\prime} 10,55^{\prime} \mathrm{T}$ & - Aktivitas domestik, industri dan wisata air \\
\hline \multirow[t]{2}{*}{ St. 2. Situ Bojongsari } & $6^{\circ} 23 ’ 15,13^{\prime} \mathrm{S}$ & - Terdapat aktivitas perumahan /domestik \\
\hline & $106^{\circ} 45^{\prime} 04,84^{\prime} \mathrm{T}$ & \\
\hline \multirow{3}{*}{ St. 3. Waduk Jatiluhur } & $6^{\circ} 32^{\prime} 28,88^{\prime \prime} \mathrm{S}$ & - Dam untuk PLTA \\
\hline & $107^{\circ} 22^{\prime} 47,07^{\prime} \mathrm{T}$ & - Aktivitas budidaya perikanan sistem KJA \\
\hline & & - Masukan dari air sungai Citarum. \\
\hline \multirow{2}{*}{ St. 4. Situ Babakan } & $6^{\circ} 20^{\prime} 28,06^{\prime \prime} \mathrm{S}$ & - Aktivitas wisata air \\
\hline & $106^{\circ} 49^{\prime} 28,80^{\prime} \mathrm{T}$ & - Domestik dan perkantoran \\
\hline \multirow[t]{2}{*}{ St. 5. Danau Sunter } & $6^{\circ} 8^{\prime} 43,74 ” S$ & - Aktivitas domestik, perkantoran, dan wisata air. \\
\hline & $106^{\circ} 52^{\prime} 56,87^{\prime} \mathrm{T}$ & \\
\hline \multirow[t]{2}{*}{ St. 6. Situ Cangkuang } & $7^{\circ} 5,54,4 ” \mathrm{~s}$ & - Aktivitas pertanian \\
\hline & $107^{\circ} 55^{\prime} 09,87^{\prime \prime} \mathrm{T}$ & - Tempat pemukiman penduduk dan aktivitas wisata air \\
\hline \multirow[t]{2}{*}{ St. 7. Situ Cibinong } & $6^{\circ} 28^{\prime} 09,52^{\prime \prime} \mathrm{S}$ & - Dekat jalan raya \\
\hline & $106^{\circ} 51^{\prime} 17,55^{\prime} \mathrm{T}$ & - Dekat aktivitas pasar tradisional \\
\hline \multirow[t]{2}{*}{ St. 8. Situ Patenggan } & $7^{\circ} 10^{\prime} 01,17^{\prime \prime} \mathrm{S}$ & - Kawasan kebun teh, relatif masih alami \\
\hline & $107^{\circ} 21^{\prime} 27,87^{\prime} \mathrm{T}$ & - Aktivitas wisata air \\
\hline \multirow[t]{2}{*}{ St. 9. Situ Burung } & $6^{\circ} 32^{\prime} 57,45^{\prime \prime} \mathrm{S}$ & - Lokasi sekitar persawahan dan domestik \\
\hline & $106^{\circ} 44^{\prime} 01,59^{\prime} \mathrm{T}$ & - Aktivitas perikanan tangkap \\
\hline \multirow[t]{2}{*}{ St. 10. Telaga Warna } & $6^{\circ} 42^{\prime} 09,36 ” \mathrm{~S}$ & - Lokasi di hutan lindung \\
\hline & $106^{\circ} 59^{\prime} 47,37^{\prime \prime} \mathrm{T}$ & - Kawasan puncak aktivitas wisata kebun teh \\
\hline \multirow[t]{2}{*}{ St. 11. Situ Cikaret } & $6^{\circ} 28^{\prime} 07,76^{\prime \prime} \mathrm{S}$ & - Dekat jalan raya Cikaret \\
\hline & $106^{\circ} 50 ’ 06,61 ” \mathrm{~T}$ & - Arena wisata air dan perumahan penduduk \\
\hline \multirow[t]{2}{*}{ St. 12. Situ Gede } & $6^{\circ} 33^{\prime} 07,77^{\prime \prime} \mathrm{S}$ & - Lokasi kawasan hutan lindung CIFOR \\
\hline & $106^{\circ} 44^{\prime} 48,34 ” \mathrm{~T}$ & - Aktivitas wisata air, perikanan masyarakat dan Domestik \\
\hline \multirow[t]{2}{*}{ St. 13. Waduk Cirata } & $6^{\circ} 41^{\prime} 49,33^{\prime \prime} \mathrm{S}$ & - Aktivitas keramba jaring apung \\
\hline & $107^{\circ} 20^{\prime} 39,14^{\prime} \mathrm{T}$ & - PLTA \\
\hline \multirow[t]{2}{*}{ St. 14. Situ Rawa Besar } & $6^{\circ} 23^{\prime} 37,76^{\prime \prime} \mathrm{S}$ & - Aktivitas wisata air \\
\hline & $106^{\circ} 48^{\prime} 57,70^{\prime} \mathrm{T}$ & - Perumahan penduduk dan pasar tradisional \\
\hline \multirow[t]{2}{*}{ St. 15. Telaga Nilam } & $6^{\circ} 47^{\prime} 14,8^{\prime \prime} \mathrm{S}$ & - Kawasan masih alami dan terjaga \\
\hline & $108^{\circ} 25^{\prime} 05,3^{\prime \prime} \mathrm{T}$ & - Kondisi air jernih \\
\hline \multirow[t]{2}{*}{ St. 16. Telaga Remis } & $6^{\circ} 47^{\prime} 33,9^{\prime \prime} \mathrm{S}$ & - Aktivitas wisata dan restoran. \\
\hline & $108^{\circ} 24^{\prime} 95,6^{\prime \prime} \mathrm{T}$ & \\
\hline \multirow[t]{2}{*}{ St. 17. Situ Ciburui } & $6^{\circ} 49^{\prime} 45,9^{\prime \prime} \mathrm{S}$ & - Dekat jalan raya Bandung \\
\hline & $107^{\circ} 28^{\prime} 06,9^{\prime \prime} \mathrm{T}$ & - Aktivitas wisata air, perumahan penduduk \\
\hline \multirow[t]{2}{*}{ St. 18. Waduk Saguling } & $6^{\circ} 55^{\prime} 08,32^{\prime \prime} S$ & - PLTA, Keramba jaring apung, industri dan penambangan pasir. \\
\hline & $107^{\circ} 29^{\prime} 01,50 " \mathrm{~T}$ & \\
\hline \multirow[t]{2}{*}{ St. 19. Situ Lido } & $6^{\circ} 44^{\prime} 36,7^{\prime \prime} \mathrm{S}$ & - Aktivitas wisata air, perumahan, perikanan dan restoran \\
\hline & $106^{\circ} 48^{\prime} 31,1^{\prime \prime} \mathrm{T}$ & \\
\hline \multirow[t]{2}{*}{ St. 20. Situ Rawa Kalong } & $6^{\circ} 23^{\prime} 43,8^{\prime \prime} \mathrm{S}$ & - Perumahan penduduk, industri dan keramba jaring apung \\
\hline & $106^{\circ} 52^{\prime} 07,1^{\prime \prime} \mathrm{S}$ & \\
\hline
\end{tabular}

Sumber : Hasil analisis.

\section{Prosedur}

Cuplikan sedimen diambil dengan menggunakan alat Ekman grab di bagian lapisan permukaan $( \pm 5 \mathrm{~cm})$. Slurry untuk analisis kimia sejumlah $1 \mathrm{~L}$ dimasukkan dalam botol polietilen dan disimpan dalam cooling box. Di laboratorium, contoh sedimen dikeringkan dalam suhu kamar (kering udara). Lima gram contoh sedimen di dekstruksi dengan menggunakan $\mathrm{HCL}-\mathrm{HNO}_{3}$ dengan perbandingan (3:1) pada suhu $100^{\circ} \mathrm{C}$ selama 8 jam dan ditambahkan larutan $\mathrm{H}_{2} \mathrm{O}_{2} \quad 30 \%$ yang dipanaskan di atas hotplate. Kadar logam berat $(\mathrm{Pb}$, $\mathrm{Cd}$, As) ditentukan dengan menggunakan alat Atomic Absorption Spectroscopy/ AAS merk Hitachi Z6100 dengan menggunakan pembakaran campuran udara - gas asetilen (Smoley, 1992).
Pengambilan hewan bentik makroavertebrata dilakukan pada kedalaman 1- 2 meter dengan menggunakan alat Ekman grab sampler sebanyak 3 kali pengambilan dan dilakukan komposit. Sampel sedimen disaring dengan ayakan yang berpori 0,5 $\mathrm{mm}$. Hewan yang tertahan dalam saringan dimasukkan dalam keler plastik yang kemudian diawetkan dengan larutan formalin $10 \%$. Identifikasi hewan cacing Oligocaheta dan larva Diptera Chironomidae dilakukan proses mounting dengan menggunakan larutan CMCP-10 (Polyscience inc.). Hewan ditaruh di atas obyek glass dan kemudian ditetesi 1 - 2 tetes larutan CMCP-10. Cover glass ditutup dan kemudian dipanaskan di atas hotplate yang bersuhu $70{ }^{\circ} \mathrm{C}$ selama 1 hari. Identifikasi spesimen dengan menggunakan mikroskop cahaya 
(100-1000 kali pembesaran) dan mikroskop stereo (80 kali pembesaran).

\section{Analisis Data}

Atribut atau metrik biologi yang digunakan dalam menentukan tingkat gangguan ekologi pada komunitas bentik makroavertebrata adalah indeks keanekaragaman Shannon-Wiener. Rumus indeks keanekaragaman Shannon-Wiener seperti pada persamaan (1):

$$
H^{\prime}=-\sum \frac{n i}{N} \log _{2} \frac{n i}{N}
$$

$\mathrm{H}^{\prime}=$ indeks keanekaragaman (bits/individu), $\mathrm{n}_{\mathrm{i}}=$ Jumlah individu dalam satu spesies, dan $\mathrm{N}=$ Jumlah total individu spesies (Cairns dan Dickson, 1971). Penghitungan indeks tersebut dilakukan dengan menggunakan perangkat lunak Spesies Diversity and Richness versi 2.65 (Pisces Conservation). Nilai dari indeks keanekaragaman dilakukan analisis statistik regresi berganda dengan kontaminasi logam berat di sedimen ( $\mathrm{Pb}, \mathrm{Cd}, \mathrm{As})$. Uji statistik regresi dilakukan dengan menggunakan software Statistica versi 5 (Stat soft Inc.).

Data komposisi dan kelimpahan bentik makroavertebrata sebelum dianalisis dengan ordinasi langsung Canonical Correspondence Analysis (CCA) ditransformasi terlebih dahulu dengan menggunakan akar kuadrat berganda guna meminimisasi pengaruh dari data kelimpahan yang terlalu ekstrim (besar). Analisis statistik CCA diterapkan guna menampakkan pengaruh faktor lingkungan pada komunitas bentik makroavertebrata. Seleksi variabel lingkungan diuji dengan menggunakan tes multikolinearitas guna menghindari variabel yang saling berautokorelasi $(\mathrm{R}>0,8$ atau nilai VIF /variance inflatation factor $>$ 5). Penghitungan statistik dari CCA dan tes multikolinearitas dilakukan dengan menggunakan software MVSP versi 3.1 (Covach Computing System).

\section{HASIL DAN PEMBAHASAN}

Hasil rerata indeks keanekaragaman pada situ dan waduk di Provinsi Jawa Barat dan Jakarta ditunjukkan dalam Gambar 2 yang sebagian besar nilainya masih tergolong rendah $\left(\mathrm{H}^{\prime}<2\right)$. Di beberapa tempat misalnya stasiun 4 (Situ Babakan), 9 (Situ Burung), 10 (Telaga Warna), 15 (Telaga Nilem), dan 16 (Telaga Remis) nilai indeksnya tergolong sedang $\left(2<\mathrm{H}^{\prime}<3\right)$. Stasiun pengamatan yang memiliki indeks keanekaragaman sedang menunjukkan jumlah taksanya relatif lebih tinggi dan dominansi yang relatif rendah oleh spesies tertentu dibandingkan stasiun lainnya yang memiliki indeks rendah $\left(\mathrm{H}^{\prime}<2\right)$.

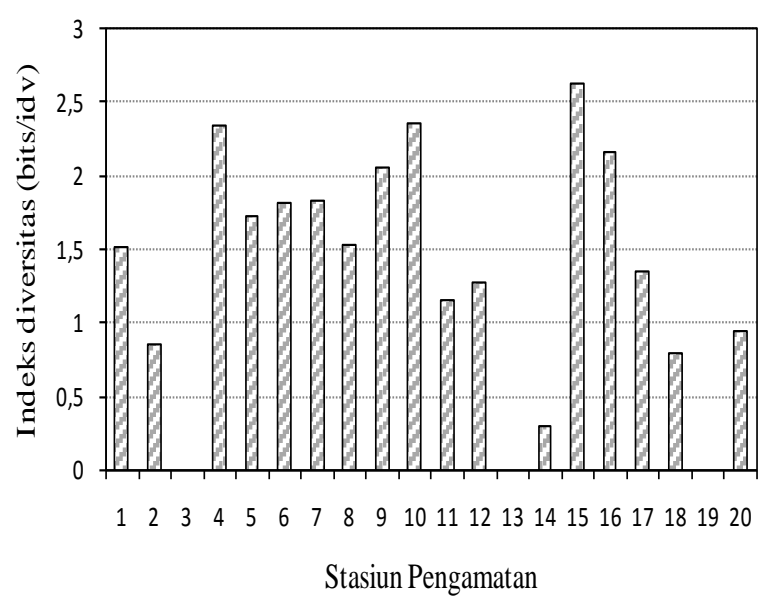

Gambar 2. Rerata indeks diversitas dari komunitas makrozoobentos di beberapa situ dan waduk di Jawa Barat.

Penelitian ini menunjukkan tingkat keanekaragaman makrozoobentos di situ dan waduk di Jakarta dan Jawa Barat tergolong rendah hingga sedang. Gangguan aktivitas antropogenik yang terjadi di sekitar situ dan waduk sebagian besar berasal dari masuknya limbah industri dan domestik, urbanisasi, maupun pertanian. Limbah perkotaan, industri, dan domestik seringkali didapati kandungan logam berat yang cukup tinggi (Factor dan Chavez, 2012). Kontaminasi logam akibat aktivitas antropogenik biasanya akan meningkatkan konsentrasi logam beberapa kali lipat di atas konsentrasi ambientnya (Gerhardt dkk., 2004). Terjadinya pemaparan logam dari sedimen maupun kolom air dapat berdampak buruk pada kehidupan organisme makrozoobentos. Hanya makrozoobentos yang toleran saja yang mampu menyesuaikan diri terhadap perubahan lingkungan akibat pencemaran logam berat seperti: Hydrophilidae, Asellidae, Ephemerellidae, Philoptamidae, Lymnaeidae, Erpobdellidae, Ephemerellidae, dan Chloroperlidae (Beasley dan Kneale, 2003).

Perubahan macam taksa maupun kelimpahan makrozoobentos merupakan respon dari sensitivitas makrozoobentos dalam mencerminkan kondisi kualitas lingkungan perairan terhadap gangguan (misalnya pencemaran). Indeks keanekaragaman menggabungkan informasi jumlah taksa, kelimpahan, maupun kemerataannya. Oleh sebab itu indeks tersebut dapat digunakan sebagai indikator dalam mencerminkan gangguan di ekosistem lentik. Sekilas tampak terjadi perubahan nilai indeks keanekaragaman mengikuti besarnya kontaminasi logam berat di sedimen. Semakin tinggi nilai indeks menunjukkan kontaminasi logam cenderung menurun. Hanya di stasiun 10 yang menunjukkan tingginya kontaminasi logam yang tidak diikuti oleh rendahnya nilai indeks keanekaragaman. Kondisi ini mungkin erat kaitannya dengan rendahnya 
bioavailabilitas logam As dan $\mathrm{Pb}$ di stasiun tersebut dalam memberikan toksisitas bagi organisme makrozoobentos. Kontaminasi logam As di Stasiun Telaga Warna kemungkinan dihasilkan dari difusi penggunaan pestisida pada area kebun teh hingga masuk ke dalam Telaga Warna. Kontaminasi logam $\mathrm{Pb}$ kemungkinan dihasilkan dari difusi partikulat asap kendaraan bermotor yang menuju daerah puncak Bogor. Bioavailabilitas logam di sedimen sangat dipengaruhi oleh ketersedian agen binding seperti bahan organik, sulfida, maupun kekuatan afinitas permukaan dari bahan partikulat penyusun sedimen (Zhang dkk., 2014). Ketersediaan bahan organik dan afinitas bahan partikulat di stasiun Telaga Warna diduga berpengaruh pada bioavailabilitas logam berat di sedimen. Sumber bahan organik di Telaga Warna dapat dihasilkan dari material organik allochtonous, karena vegetasi di sekitar telaga masih cukup lebat.

Kontaminasi logam As, $\mathrm{Pb}$, dan Cd di sedimen (Gambar 3) menunjukkan tingkat kontaminasi yang bervariasi. Kontaminasi kadmium menunjukkan hampir di semua stasiun pengamatan kontaminasinya relatif rendah, dan hanya stasiun 20 (Waduk Saguling) yang memiliki kontaminasi logam kadmium lebih tinggi. Guideline kualitas sedimen low effect level /LEL-Cd dari negara Canada (Ontario) menunjukkan nilai ambang batasnya sebesar 0,6 ppm. Hanya di stasiun 20 yang melebihi guideline tersebut. Kondisi ini menunjukkan potensi logam kadmium dalam memberikan kontribusi pada kejadian toksisitas ada, walaupun efek merugikan yang ditimbulkan masih tergolong rendah.

Kontaminasi logam arsen di sedimen menunjukkan hampir sebagian besar stasiun pengamatan melebihi nilai LEL (6 ppm). Di stasiun
10 (Telaga Warna), 11 (Cikaret), 12 (Situ Gede), 13 (Cirata), dan 14 (Rawa besar) kontaminasi logam arsennya melebihi dari nilai severe effect level/SELAs sebesar 33 ppm. Hanya di stasiun 15 (Telaga Nilem), 16 (Telaga Remis), 17 (Ciburui), dan 19 (Lido) kontaminasinya masih jauh di bawah dari nilai LEL-As. Stasiun yang memiliki nilai konsentrasi di atas dari ambang batas SEL menunjukkan potensi seringnya logam tersebut menimbulkan efek yang merugikan bagi biota perairan.

Kontaminasi logam $\mathrm{Pb}$ di sedimen sebagian besar masih di bawah nilai LEL (31 ppm) kecuali Stasiun 1 (Cibereum), 5 (Sunter), 7 (Cibinong), 10 (Telaga Warna), 14 (Rawa Besar), dan 20 (Rawa Kalong) yang lebih tinggi dari nilai LEL-Pb. Kondisi itu menunjukkan bahwa potensi kemungkinan kejadian toksisitas oleh logam $\mathrm{Pb}$ di sedimen di stasiun yang melebihi nilai LEL relatif lebih tinggi, jika dibandingkan dengan stasiun yang konsentrasinya masih di bawah nilai LEL.

Gambar 2 dan 3 menunjukkan bahwa di sebagian besar stasiun pengamatan yang memiliki konsentrasi di atas LEL dan SEL kecenderungannya nilai indeks keanekaragaman tergolong rendah $\left(H^{\prime}<2\right)$. Stasiun dengan indeks keanekaragaman $\mathrm{H}^{\prime}>2$ cenderung kontaminasi logam di sedimennya rendah (di bawah guideline SEL-As atau LEL-Pb). Hanya di Stasiun 10 (Telaga Warna) yang menunjukkan kontaminasi logam $\mathrm{Pb}$ dan As yang relatif tinggi, namun tidak diikuti dengan rendahnya indeks keanekaragaman $(\mathrm{H}>2)$.

Konsentrasi logam di sedimen pada sebagian besar stasiun pengamatan telah melampaui LEL-As, dan di beberapa tempat melebihi SEL-As dan LEL$\mathrm{Pb}$. Stasiun dengan nilai di atas LEL menunjukkan potensi terjadinya toksisitas oleh

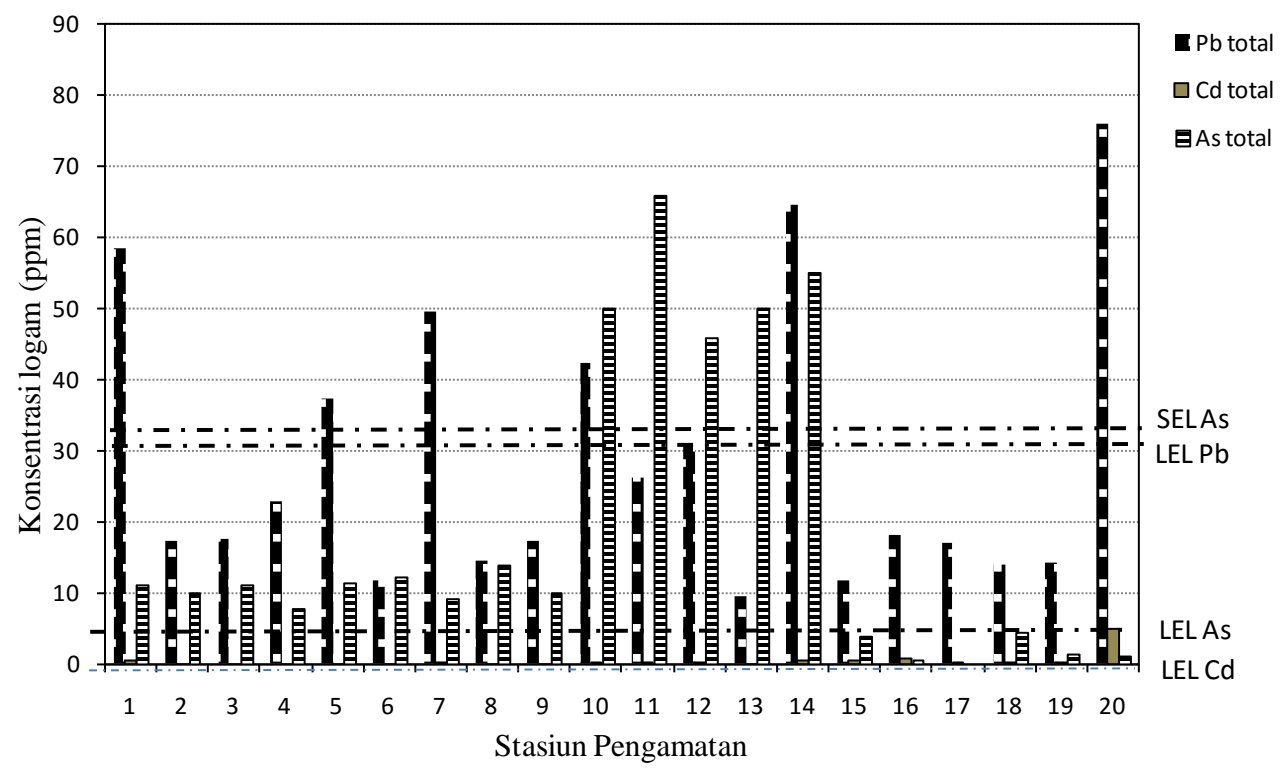

Gambar 3. Kontaminasi logam $\mathrm{Pb}$, Cd, dan As di beberapa situ dan waduk di Jawa Barat. 
logam kadangkala terjadi, sedangkan yang di atas SEL menunjukkan toksisitas sering terjadi (Salem dkk., 2014). Sumber kontaminasi logam Pb mungkin berasal dari pembakaran bahan bakar fosil oleh asap kendaraan bermotor. Faktor hujan dapat mengangkut bahan partikulat yang mengandung logam berat masuk ke perairan. Sumber logam As di perairan biasanya berasal dari penggunaan pestisida, ekstraksi sumber air tanah, maupun limbah industri seperti: farmasi, tekstil, gelas, kertas dan sebagainya (Henke 2009). Keberadaan logam kadmiun di lingkungan perairan kemungkinan dihasilkan dari pelindian penggunaan pupuk fosfat, sewage sludge, maupun dari limbah industri misalnya pabrik baterai, pewarna, pigmen maupun plastik (Anonim, 2008 ${ }^{\mathrm{b}}$ ).

Hasil analisis regresi berganda antara kontaminasi logam berat di sedimen dengan indeks keanekaragaman ditunjukkan dalam persamaan $\mathrm{Y}=$ $0,22(\mathrm{~Pb})+0,94(\mathrm{Cd})-0,77(\mathrm{As})+2,102$. Hasil analisis menunjukkan nilai koefesien determinasi relatif tinggi $\left(\mathrm{R}^{2}\right.$ yang di atur /adjusted $=0,643$ ) dan koefiesien korelasinya $(r=0,83)$. Hasil analisis lebih lanjut dengan menggunakan uji Anova menunjukkan hubungan yang sangat signifikan antara kontaminasi logam As $(\mathrm{p}=0,000)$ dengan indeks keanekaragaman, namun kontaminasi untuk logam $\mathrm{Pb}(\mathrm{p}=0,137)$ dan $\mathrm{Cd}(\mathrm{p}=0,515)$ di sedimen menunjukkan hubungan yang lemah dengan indeks keanekaragaman. Hubungan linieritas antara kontaminasi logam As di sedimen dengan indeks keanekaragaman ditunjukkan dalam persamaan regresi y = 1,97-0,0139x (Gambar 4). Gambar 4 menunjukkan pola kecenderungan menurun dari nilai indeks keanekaragaman dengan peningkatan kontaminasi logam arsen di sedimen.

Gambar 3 menunjukkan kontaminasi logam arsen di sedimen terlihat sangat tinggi (di atas dari SEL-As), sehingga kemungkinan toksisitas yang ditimbulkan oleh logam arsen pada organisme makrozoobentos semakin besar. Hasil analisis regresi (Gambar 4) juga menunjukkan bahwa logam berat arsen berkontribusi secara signifikan terhadap indeks keanekaragaman. Pengaruh logam arsen pada organisme makrozoobentos telah dipelajari oleh beberapa peneliti. Ansaldo dkk., (2009) menunjukkan pengaruh logam arsen pada siput Biomphalaria glabrata yaitu dapat memperpanjang lama waktu penetasan dan menurunkan fekunditas siput. Penelitian dari Factor dan Chavez, (2012) menunjukkan toksisitas kronis dari logam As, Cr, $\mathrm{Al}$, dan Ni pada embrio siput Radix quadrasi berupa keterlambatan pertumbuhan, kecacatan bentuk, edema, hingga penipisan cangkang. Ion logam berat dapat membentuk ikatan kompleks pada gugus sulfidril $(-\mathrm{SH})$ dan $(-\mathrm{OH})$

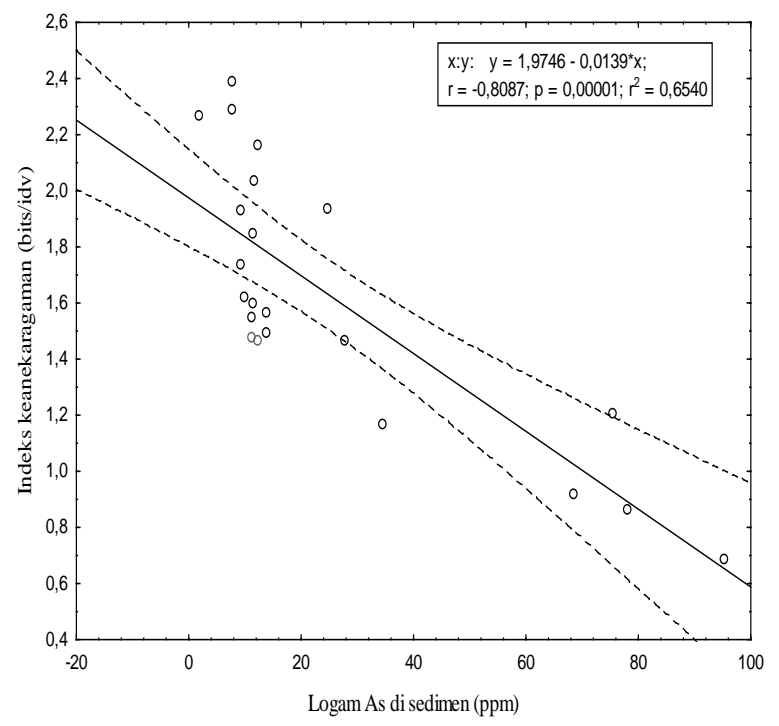

Gambar 4. Hubungan antara kontaminsi logam arsen di sedimen dengan indeks keanekaragaman.

dalam enzim mitokondria yang mampu menghalangi sintesis dan fosforilasi protein yang terlibat dalam proses metabolik. Logam Arsen dapat menghambat sintesis ATP yang terlibat dalam siklus asam sitrat dan sistem transport fosfat. Kondisi ini akan menghentikan kerja enzim dehidrogenase piruvat dan meningkatkan pirufat dalam hemolymph, sehingga secara bertahap akan menyebabkan kerusakan pada sel. Pada skala yang lebih luas, kontaminasi logam secara terus menerus dapat menimbulkan toksik akut bagi sebagian besar biota akuatik. Kondisi ini dapat mempengaruhi kelimpahan maupun jumlah taksa yang mampu bertahan hidup akibat terpapar oleh logam arsen yang pada akhirnya mempengaruhi indeks keanekaragamannya.

Hasil analisis ordinasi dengan menggunakan CCA (Gambar 5) menunjukkan perolehan nilai eigenvaluenya pada sumbu 1 dan 2 sebesar 0,45 dan 0,418 dengan persentase kumulatif constrained yang terjelaskan sebesar 50,38\%. Pada gambar grafik triplot CCA menunjukkan ada lima grup/kelompok. Kelompok I adalah stasiun 2 dan 13, kelompok II adalah stasiun 11 dan 10, kelompok III adalah stasiun 15, kelompok IV adalah stasiun 17, 18,19, dan kelompok ke $\mathrm{V}$ adalah sisa stasiun lainnya yang ada. Pada grafik tersebut menunjukkan hewan yang ada di sebelah sisi kanan kuadran seperti larva Coleoptera Simsonia sp., lintah Placobdella sp., larva chironomid Ablabesmyia sp., dan Tanytarsus sp. lebih dicirikan oleh kontaminasi logam arsen di sedimen yang tinggi, $\mathrm{pH}$ dan suhu yang rendah. Namun sebaliknya untuk siput Melanoides sp. cenderung menyukai $\mathrm{pH}$ yang relatif tinggi dan kontaminasi logam arsen yang rendah. Adapun spesies lainnya 


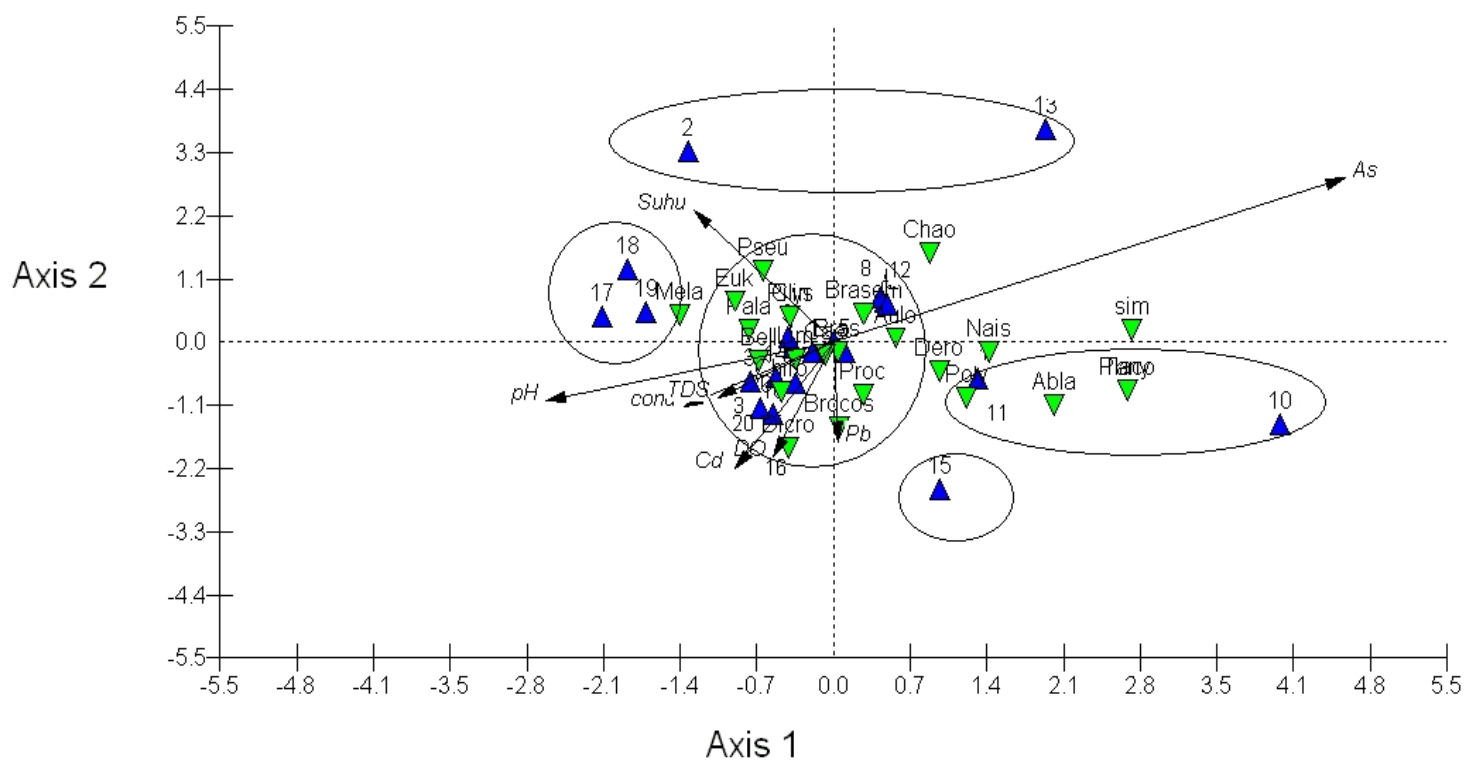

Vector scalina: 5.80

Gambar 5. Grafik triplot ordinasi CCA komunitas makrozoobentos di situ dan waduk di Jawa Barat.

yang cenderung berpusat di tengah sumbu ordinasi yang merupakan spesies umum yang dapat ditemukan hampir di sebagian besar lokasi stasiun pengamatan (stasiun 1, 3, 5, 6, 8, 9, 12, 14, 16, 20).

Hasil ordinasi dengan menggunakan CCA menunjukkan preferensi dari setiap taksa makrozoobentos dengan variabel lingkungan yang digunakan dalam penelitian ini. Keberadaan taksa Chironomid misalnya Ablabesmyia sp., dan Tanytarsus sp, lintah Placobdella sp., dan larva kumbang elmid Simsonia terlihat lebih toleran terhadap peningkatan logam arsen di sedimennya. Keberadaan larva Chironomid dan cacing Oligochaeta di lingkungan akuatik telah dilaporkan oleh Arslan dkk., (2010) relatif tahan terhadap kontaminasi logam berat di sedimen. Genus Ablabesmyia dan Tribelos menunjukkan relatif toleran terhadap polusi organik secara umum, dan keasaman air cenderung rendah (Montalto dan Paggi, 2006)

Lintah Placobdella sp. terlihat cenderung toleran terhadap kontaminasi logam berat di sedimen. Friese dkk., (2003) yang menggunakan lintah Erpobdella octulata memiliki resistensi fisiologi terhadap kontaminasi logam dan kemampuan akumulasi terhadap logam, sehingga dapat digunakan sebagai bioindikator perairan. Larva elmid Simsonia sp. cenderung relatif toleran terhadap kontaminasi logam di sedimen. Kumbang elmid cenderung menyukai kondisi yang alkalin dan mampu bertahan hidup pada kondisi sungai yang menerima air asam tambang (Ross dkk., 2008). Larva kumbang elmid juga dilaporkan relatif tahan terhadap buangan geotermal (Clements $d k k ., 2011)$. Keberadaan moluska Melanoides sp. yang cenderung menyukai $\mathrm{pH}$ yang relatif tinggi dan kontaminasi logam arsen yang rendah. Kondisi ini mungkin ada kaitannya dengan sensitifitas hewan tersebut terhadap logam arsen yang cukup tinggi maupun keperluan hewan tersebut dalam membuat cangkang yang butuh banyak unsur kalsium atau cenderung basa

\section{KESIMPULAN}

Kontaminasi logam berat di sedimen terutama arsen dapat menimbulkan rendahnya dari indeks keanekaragaman yang ada di ekosistem lentik (situ dan waduk) di Jawa Barat. Larva Chironomid Ablabesmyia sp., dan Tanytarsus sp, lintah Placobdella sp., dan larva kumbang elmid Simsonia terlihat lebih toleran terhadap peningkatan logam berat arsen di sedimen.

\section{UCAPAN TERIMAKASIH}

Peneliti mengucapkan banyak terima kasih rekan-rekan analis kimia Puslit Limnologi-LIPI seperti Ibu Rosidah, Fajar Sumi dan lainnya yang telah meluangkan waktunya dalam menganalisis logam berat di sedimen. Peneliti juga mengucapkan banyak terima kasih pada Ibu Laela Sari yang banyak membantu dalam sortir makrozoobentos.

\section{DAFTAR PUSTAKA}

Anjani, A., Hasan Z., dan Rosidah, 2012, Kajian Penyuburan dengan Bioindikator Makrozoobentos dan Substrat di Situ Bagendit 
Kabupaten Garut, Jawa Barat. Jurnal Perikanan dan Kelautan, 3(3):253-262.

Anonim, 2008a, http://cetak.kompas.com/read/xml/ 2008/10/17/10325676/ratusan.situ.di.jabar. beralih.fungsi.menjadi.permukiman, diakses 30 Januari 2009.

Anonim, 2008, Case Studies in Environmental Medicine (CSEM): Cadmium Toxicity, Atlanta, Georgia, 63pp.

Anonim, 2015. Fungsi dan Manfaat Situ, http://lingkunganhijau.com/fungsi-danmanfaat-situ/, [diakses tanggal 26 januari 2015]

Ansaldo, M., Nahabedian, D.E., Di Fonzo, C., dan Wider, E.A., 2009. Effect of Cadmium, Lead and Arsenic on the Oviposition, Hatching and Embryonic Survival of Biomphalaria glabrata. Sci. Total Environ., 497:1923-1928.

Arslan, N., Koç, B., dan Çiçek, A., 2010. Metal Contents in Water, Sediment, and Oligochaeta- Chironomidae of Lake Uluabat, a Ramsar Site of Turkey. The Scientific World Journal, 10:1269-1281.

Appenroth, K.J., 2010. Definition of "Heavy Metals" and Their Role in Biological Systems, Chapter 2, I. Sherameti and A. Varma (eds.), Soil Heavy Metals, Soil Biology, Vol 19. Springer-Verlag Berlin Heidelberg, pp 19-29.

Baldwin, D.S., dan Howitt, J., 2007. Baseline Assessment of Metals and Hydrocarbons in the Sediments of Lake Mulwala, Australia. Lakes and Reservoirs: Research and Management 12(3):167-174.

Beasley, G., dan Kneale, P.E., 2003. Investigating the Influence of Heavy Metals on Macroinvertebrate Assemblages using Partial Canonical Correspondence Analysis (pCCA). Hydrology and Earth System Sciences, 7(2):221-233.

Callisto, M., Goulart, M., Barbosa, F., dan Rocha, A.R., 2005. Biodiversity Assessment of Benthic Macroinvertebrates Along A Reservoir Cascade in The Lower São Francisco River (Northeastern Brazil). Braz. J. Biol., 65(2):229-240.

Cairns, J.J, dan Dickson, K.L. 1971. A Simple Method for The Biological Assessment of The Effects of Waste Discharges on Aquatic Bottom-Dwelling Organisms. Journal Water Pollution Control Federation, 43(5):755.

Clements, W.H., Arnold, J.L., Koel, T.M., Daley R., dan Jean, C., 2011. Responses of Benthic Macroinvertebrate Communities to Natural Geothermal Discharges in Yellowstone National Park, USA. Aquat. Ecol., 45:137149.
Doi, H., Takagi, A., dan Kikuchi, E., 2007. Stream Macroinvertebrate Community Affected by Point-Source Metal Pollution. Internat. Rev. Hydrobiol. 92(3):258-266.

Di Veroli, A., Santoro, F., Pallottini, M., Selvaggi, R., Scardazza F., Cappelletti D., dan Goretti, G., 2014. Deformities of Chironomid Larvae and Heavy Metal Pollution: from Laboratory to Field Studies. Chemosphere, 112:9-17.

Factor, C.J.B., dan Chavez, E.R.C., 2012. Toxicity of Arsenic, Aluminum, Chromium and Nickel to the Embryos of The Freshwater Snail, Radix Quadrasi von Möellendorf 1898. Philippine Journal of Science 141(2):207-216.

Farkas, A., Erratico, C., dan Vigano, L., 2007. Assessment of the Environmental Significance of Heavy Metal Pollution in Surficial Sediments of the River Po. Chemosphere, 68:761-768.

Friese, K., Frömmichen, R., Witter, B., dan Müller, H., 2003. Determination of Trace Metals in The Freshwater Leech Erpobdella octuculata of The River Elbe-Evaluation of The Analytical Protocol. Acta Hydrochim. Hydrobiol., 31:346-355.

Gerhardt, A., Bisthoven, L.J., dan Soares, A.M.V.M., 2004. Macroinvertebrates Response to Acid Maine Drainage: Community Structure and On-line Behavioral Toxicity Bioassay. Environmental Pollution 130:263-274.

Henke, K., 2009. Arsenic in Natural Environments, in: Arsenic Environmental Chemistry,Health Threats, and Waste Treatment, K. henke (sds), John \& Wiley Sons ltd., West Sussex, pp 69235.

Khaled, A., Nemr, E., dan Sikaily, E.A., 2006. An Assessment of Heavy-metal Contamination in Surface Sediments of the Suez Gulf Using Geoaccumulation Indexes and Statistical Analysis. Chemistry and Ecology 22(3):239252.

Mayer-Pinto, M., Underwood, A.J., Tolhurst, T., dan Coleman, R.A., 2010. Effects of Metals on Aquatic Assemblages: What do We really Know?. Journal of Experimental Marine Biology and Ecology, 391:1-9.

Moreno, P., dan Callisto, M., 2006. Benthic Macroinvertebrates in the Watershed of an Urban Reservoir in Southeastern Brazil. Hydrobiologia, 560:311-321.

Montalto, L., dan Paggi, A.C., 2006. Diversity of Chironomid Larvae in a Marginal Fluvial Wetland of the Middle Paraná River floodplain. Argentina, Ann. Limnol. - Int. J. Lim. 42(4):289-300. 
Pham, N.T., Pulkownik, A., dan Buckney, R.T., 2007. Assessment of Heavy Metals in Sediments and Aquatic Organisms in West Lake (Ho Tay), Hanoi, Vietnam. Lakes \& Reservoirs: Research and Management 12:285-294.

Prica, M., Dalmajica B., Roncevic, S., Kremar, D., dan Bacelic M., 2007. A Comparison of Sediment Quality Results with Acid Volatile Sulfide (AVS) and Simultaneously Extracted Metal (SEM) Ratio in Vojvodina (Serbia) Sediments. Sci. Total Environ., 20:1-10.

Rippey, B., Rose, N., Yang, H., Harrad, S., Robson, M., dan Travers, S., 2007. An assessment of Toxicity in Profundal Lake Sediment Due to Deposition of Heavy Metals and Persistent Organic Pollutants from the Atmosphere. Environment International, 34:345-356.

Rossaro, B., Marziali, L., Cardoso, A.C., Solimini, A., Free, G., dan Giacchini, R., 2007, A Biotic Index Using Benthic Macroinvertebrates for Italian Lakes. Ecological Indicators 7:412429.

Ross, R.M., Long, E. S., dan Dropkin, D.S., 2008. Response of Macroinvertebrate Communities to Remediation-Simulating Conditions in Pennsylvania Streams Influenced by Acid Mine Drainage. Environ. Monit. Assess. 145:323-338.

Salem, D.M.S., Khaled, A., El-Nemr, A., dan ElSikaily, A., 2014. Comprehensive Risk Assessment of Heavy Metals in Surface Sediments Along the Egyptian Red Sea Coast. Egyptian Journal of Aquatic Research 40:349-362.

Smoley, CK., 1992. Methods for The Determination of Metals in Environmental Samples, 200.2. US-EPA.Cincinnati.

Tall, L., Méthot1, G., Armellin, A., dan Bernadette, P.A., 2008. Bioassessment of Benthic Macroinvertebrates in Wetland Habitats of Lake Saint-Pierre (St. Lawrence River), $J$. Great Lakes Res. 34:599-614.

Zhang, C., Yu, Z., Zeng, G., Jiang, M., Yang, Z., Cui, F., Zhu, M., Shen, L., dan Hu, L., 2014. Effects of Sediment Geochemical Properties on Heavy Metal Bioavailability. Environment International 73:270-281. 